Zaremba-Warnke S., Accomplishment of the economics of sustainable development as an opportunity to build a competitive advantage, „Ekonomia i Prawo. Economics and Law.”, Polszakiewicz B., Boehlke J. (ed.), Vol. 14, No. 1/2015, pp. 81-93. DOI: http://dx.doi.org/10.12775/ EiP.2015.006.

\title{
ACCOMPLISHMENT OF THE ECONOMICS OF SUSTAINABLE DEVELOPMENT AS AN OPPORTUNITY TO BUILD A COMPETITIVE ADVANTAGE
}

\author{
SUMMARY
}

Currently creating economics of sustainable development is an alternative concept in relation to neoclassical economics. The aim of economics of sustainable development is sustainable management, which means to guarantee high economic, ecological and socio-cultural standards for present and future generations within the limits of environment's natural resistance. The accomplishment of sustainable development concept requires the activeness of all socio-economic subjects, particulary the ones which should play a key role - enterprises. Although, more companies pay attention to social results of their activities, so the ones which really act in accordance with the principles of sustainable development, still constitute a minority on the market. The assumption of economics of sustainable development, in practice - enterprise management come to so called three strategic paths i.e. effectiveness, cohesion and sufficiency. It also leads to fulfill sustainability criteria, which can be divided into three main groups i.e. ecological, economic and socio-cultural ones. Accomplishment of sustainable development assumptions constitutes an opportunity to build a durable competitive advantage in enterprises.

The purpose of this article is to characterize the assumptions of economics of sustainable development in relation to enterprise management and to point out a possi-

* Sabina Zaremba-Warnke, Wrocław University of Economics, Faculty of Management, Economics and Tourism, Department of Quality and Environmental Management, ul. Nowowiejska 3, 58-506 Jelenia Góra, phone: +48 7575382 57, e-mail: Sabina.Zaremba@ ue.wroc.pl. 
bility to build a competitive advantage by enterprises acting in accordance with sustainable development principles.

Keywords: sustainable enterprise, sustainable management, competitiveness of enterprises

JEL Classification: Q01, M14

\section{INTRODUCTION}

Present civilization deals with many serious socio-economic problems. The most important one is natural environment pollution, which constitutes a natural basis of life and all human being's activity. Such problems like: climate change, ozone layer shrinking, ecosystems degradation, biodiversity endangerment and environment poisoning, and connected with it, a negative impact on man's health, endangerment of renewable resources ${ }^{1}$, a change of consumption models from resource-saving into the ones focused on spiritual values, and from long-period into wasteful and concentrated on material values, and short-term, an increasing risk of control of most world markets by international corporations, lead to deterioration of the quality of life $^{2}$. In the second half of XX century it became obvious that, a continuation of current, narrowly understood economic development, will not provide a stable improvement of economic, ecological and social conditions, for both present and future generations ${ }^{3}$.

An alternative concept of development is sustainable development. On "Earth Summit" in Rio de Janeiro, the idea of sustainable development assumed to be a new global $\mathrm{aim}^{4}$. The accomplishment of sustainable development requires a change of approach towards management process and that is why, many economists postulate to replace the assumptions of neoclassical economics with economics of sustainable development. Neoclassical economics treats natural resources as one of production factor and its aim is their optimal usage. The aim of economics of sustainable development is so called sustainable management, which means to guarantee high economic, ecologi-

${ }^{1}$ E.g. intensive fishing leading to species extinction.

${ }^{2}$ Cf. e.g. H. Rogall, Bausteine einer zukunftsfähigen Umwelt und Wirtschaftspolitik, Duncker \& Humbolt, Berlin 2000, p. 38-49.

${ }^{3}$ Cf. e.g. E. Kośmicki, Nachhaltiger Konsum und das Welternährungsmodel, [in:] M. Wachowiak, D. Kiełczewski, H. Diefenbacher (eds), Nachhaltiger Konsum? Die Entwicklung des Verbraucherverhaltens in Polen und Deutschland, FEST, Heidelberg 2011, p. 197-201.

${ }^{4}$ Instytut Ochrony Środowiska, Dokumenty końcowe Konferencji Narodów Zjednoczonych „Środowisko i Rozwój” w Rio de Janeiro w 1992 r., Warszawa 1993, p. 13-15. 
cal and socio-cultural standards for present and future generations within the limits of environment's natural resistance ${ }^{5}$.

The accomplishment of sustainable development concept requires the activeness of all socio-economic subjects, but one should emphasize that, an enterprise should play a key role in this field. Although, more companies pay attention to social results of their activity, so the ones which really act in accordance with the principles of sustainable development, for which they are not only a marketing slogan, still constitute a minority on the market. However, a practice shows, that acting in accordance with sustainable development principles constitutes an opportunity to build a durable competitive advantage for local, regional as well as domestic and international companies.

The purpose of this article is to characterize the assumptions of economics of sustainable development in relation to enterprise management and to point out a possibility to build a competitive advantage by enterprises, acting in accordance with sustainable development principles.

\section{ASSUMPTIONS OF ECONOMICS OF SUSTAINABLE DEVELOPMENT}

The economics of sustainable development is a new science discipline, which is just shaping as a separate research direction in the field of economic sciences. Its fundamentals were shaped on the basis of environmental economics and ecological economics, and connected with it research on sustainable development. In Poland, theoretical and implementary aspects of sustainable development concept were propagated by many economists ${ }^{6}$. One of the most known foreign propagator of sustainable development concept is a German economist Holger Rogall ${ }^{7}$.

The economics of sustainable development precises a definition of sustainable development accepted during "Earth Summit" in 1992, putting an emphasis on the fact that, "sustainable development leads to provide all currently living people and future generations high enough ecological, economic

${ }^{5}$ H. Rogall, Ekonomia zrównoważonego rozwoju, ZYSK i S-KA, Poznań 2010, p. 85-86.

${ }^{6}$ Cf. e.g.: D. Kiełczewski (ed.), Od koncepcji ekorozwoju do ekonomii zrównoważonego rozwoju, Wydawnictwo WSE w Białymstoku, Białystok 2009; B. Poskrobko (ed.), Ekonomia zrównoważonego rozwoju w świetle kanonów nauki, Wydawnictwo WSE w Białymstoku, Białystok 2011; B. Poskrobko (ed.), Teoretyczne aspekty ekonomii zrównoważonego rozwoju, Wydawnictwo WSE w Białymstoku, Białystok 2011.

${ }^{7}$ Cf. e.g.: H. Rogall, Nachhaltige Ökonomie, Metropolis, Marburg 2009; H. Rogall, Ökonomie der Nachhaltigkeit. Handlungsfelder für Politik und Wirtschaft, VS - Verlag, Wiesbaden 2004; H. Rogall, Neue Umweltökonomie - Ökologische Ökonomie, Leske+Budrich, Opladen 2002. 
and socio-cultural standards in the limits of the Earth's natural resistance, applying a principle of inter-generational and intra-generational justice ${ }^{8}$.

Basic assumptions of the economics of sustainable development are as follows':

- present model of development, which assumes a lack of absolute environmental borders of development is rejected, and instead of its place, the existence of absolute natural borders is assumed; a new approach is necessary, which will expose durability management, based on long-term natural resources' conservation;

- current paradigm of growth has to be replaced by sustainable development paradigm (so called selective growth), because a rapid growth, together with a parallel fulfillment of the possibility of natural resources usage through thousands years, is impossible;

- the economics of sustainable development is based on ethical principles and emphasizes a necessity to take personal activities for sustainable development. Basic values are responsibility and inter, and intra-generational justice;

- in the analysis of economic process one should accept interdisciplinary approach including socio-ecological correlations. A crucial role plays here mutual use of research results and close cooperation of economics with political, legal and nature studies, also engineering ones;

- there is a necessity for framework changes of management, using political and legal instruments, in a way, which will improve perspectives for long-term remain of resources, for consumers and producers;

- differently than in traditional economics, the quality of life and material goods should not be identified with each other, and counted as a gross domestic product per capita;

- representatives of the economics of sustainable development reject Orthodox free market economy, as well as the economies centrally concentrated on the system of market economy having socio-ecological framework order - to decrease results evoked by market mechanisms failure, there is a need for an active intervention from state policy.

The economics of sustainable development clearly goes beyond ecological objectives, including economic and socio-cultural dimension of future society. The economics of sustainable development does not ignore natural Earth's

${ }^{8}$ H. Rogall, Ekonomia..., op. cit., p. 44.

${ }^{9}$ Cf. e.g.: H. Rogall, Podstawowe zatożenia ekonomii zrównoważonej, [in:] D. Kiełczewski (ed.), Od koncepcji ekorozwoju do ekonomii zrównoważonego rozwoju, Wydawnictwo WSE w Białymstoku, Białystok 2009, p. 77-79. 
resistance and this is what distinguishes it from most taken activities after "Earth Summit"10.

\section{ENTERPRISE MANAGEMENT IN ACCORDANCE WITH THE ASSUMPTIONS OF ECONOMICS OF SUSTAINABLE DEVELOPMENT}

As mentioned, the accomplishment of sustainable development requires engagement from all socio-economic subjects, the ones, which should play a key role in this area should be enterprises ${ }^{11}$.

In practice of enterprise management, the accomplishment of economics of sustainable development assumptions lead to the application of many different means and instruments, which can be subscribed to three long-term strategic paths, characterized by $\mathrm{H}$. Rogall in the following way ${ }^{12}$ :

1. Effectiveness strategy - its aim is a tenfold increase of resources efficiency; it means that, already existing products are changed in a way to make the use of resources more efficient, including the reduction of pollution emissions;

2. Cohesion strategy - it is designing new products, which satisfy the requirements of sustainable development;

3. Sufficiency strategy - assumes voluntary deciding on a gradual change of people's own life in a socially responsible way i.e. its development, according to inter-generational and intra-generational principle of justice. The most important aim of this strategy is to reduce consumption of natural resources because the limits of tolerance have already been used up.

Effectiveness strategy is relatively the easiest for an enterprises. It can concern not only product but also all processes taking place in an enterprise. Dynamically developing markets of pro-ecological production solutions and the popularity of quality and environment management systems (e.g. ISO 14 000, EMAS), enable mangers to increase effectiveness of resources' usage, with a reduction in emissions. In a longer time period, the application

${ }^{10}$ Cf. H. Rogall H, Ekonomia..., op. cit., p. 49-50.

${ }^{11}$ Cf. e.g.: P. Söderbaum, Understanding Sustainability Economics, Earthscan, London 2008, p. 79-80, 88-91; A. Oberholz, Umweltorientierte Unternehmensführung, Frankfurter Allgemeine Zeitung, Frenkfurt (Mein) 1990, p. 68, H. Rogall, Neue..., op. cit., , p. 165-167.

${ }_{12}$ Cf. H. Rogall H, Ekonomia..., op. cit., p. 168. 
of this strategy means lower costs, because pro-ecological solutions are resource-saving ${ }^{13}$.

Cohesion strategy is more difficult, it means higher risk and higher costs than in effectiveness strategy, it requires innovative solutions, designing and launching on market new products and applying in an enterprise innovative, pro-ecological products and processes. If one assumes that, an enterprise has environmental management system, cohesion strategy is a natural consequence of effectiveness strategy. It results from the fact that, a requirement for continuous improvement sooner or later, will lead to a conclusion that, applying only effectiveness strategy is not enough to make an enterprise function in accordance with sustainable development principles.

Sufficiency strategy is the most difficult and the least popular one. In relation to an enterprise it stands for verification of its activity, from the view of widely understood social responsibility. For many enterprises, it can even mean a total change of activity profile. It also combines with building ecological awareness and social sensibility, of both an enterprise's employees and subjects of its surrounding, particulary consumers and cooperators.

To the assessment of sustainability of products and processes in an enterprise, representatives of economics of sustainable development suggest a set of sustainable development criteria (cf. table 1).

Table 1. Purposeful criteria for sustainability assessment of products and processes in enterprise

\begin{tabular}{|c|c|c|}
\hline $\begin{array}{l}\text { GROUP } \\
\text { OF CRITERIA }\end{array}$ & CRITERION & CHARACTERISTICS OF CRITERION \\
\hline \multirow{6}{*}{ 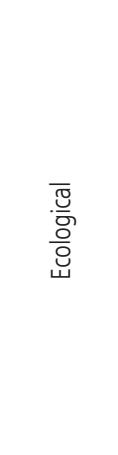 } & Harmlessness for climate & Energy usage sources from fossil fuels (goal: resigning from using) \\
\hline & $\begin{array}{l}\text { Harmlessness for natural } \\
\text { landscape }\end{array}$ & $\begin{array}{l}\text { Urbanization of natural areas (goal: resigning from additional urbaniza- } \\
\text { tion of natural areas) }\end{array}$ \\
\hline & Harmlessness for nature & Influence on biodiversity (goal: biodiversity protection) \\
\hline & $\begin{array}{l}\text { Usage of non-renew- } \\
\text { able resources }\end{array}$ & $\begin{array}{l}\text { Exploitation of non-renewable resources (goal: limitation of secondary } \\
\text { materials or constantly available ones) }\end{array}$ \\
\hline & $\begin{array}{l}\text { Usage of renewable re- } \\
\text { sources }\end{array}$ & $\begin{array}{l}\text { Exploitation of renewable resources (goal: the usage of only renewable } \\
\text { resources, which can be managed in a pro-ecological way) }\end{array}$ \\
\hline & Health hazards & $\begin{array}{l}\text { Using toxic materials and emissions of harmful substances (goal: stop- } \\
\text { page of usage and emission) }\end{array}$ \\
\hline
\end{tabular}

${ }^{13}$ Cf. e.g.: M. Gege, Kosten senken durch Umweltmanagement, Verlag Vahlen, München 1997, p. 53-59, 65-564; W. Scheide, G. Dold, S. Enzler, Efficient Eco-Management Using. ECOIntegral - How to Save Costs and Natural Resources at the Same Time, [in:] M. Bennett, J. Jaap Bouma, T. Wolters (eds), Environmental Management Accounting: Informational and Institutional Developments, Kluwer Academic Publishers, Dordrecht 2002, p. 93-111. 


\begin{tabular}{|c|c|c|}
\hline $\begin{array}{l}\text { GROUP } \\
\text { OF CRITERIA }\end{array}$ & CRITERION & CHARACTERISTICS OF CRITERION \\
\hline \multirow{5}{*}{ 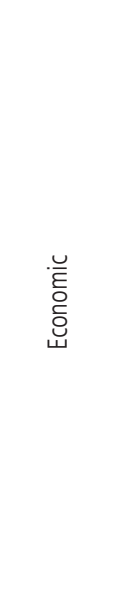 } & Economic effects & $\begin{array}{l}\text { Significance for national economy through created values and employ- } \\
\text { ment level (goals: high employment level with a satisfactory compensa- } \\
\text { tion, keeping acceptable quality of work standards) }\end{array}$ \\
\hline & $\begin{array}{l}\text { Satisfying needs, prop- } \\
\text { er prices }\end{array}$ & $\begin{array}{l}\text { Reliability, durability, proper prices (goals: reliability, timeless design, } \\
\text { multi-functionality, honest purchase price, providing satisfactory profit } \\
\text { and compensation for work, price availability for most society and low } \\
\text { exploitation costs) }\end{array}$ \\
\hline & $\begin{array}{l}\text { Inflation effects, influ- } \\
\text { ence on capital concen- } \\
\text { tration }\end{array}$ & $\begin{array}{l}\text { Inflation effects (goals: price stability, decrease of prices and the level } \\
\text { of capital concentration, effective competition) }\end{array}$ \\
\hline & $\begin{array}{l}\text { Dependency from re- } \\
\text { source supply }\end{array}$ & $\begin{array}{l}\text { Transport intensity (goals: as many resources and products should come } \\
\text { from one's own region as seems to be rational from ecological point } \\
\text { of view, and be responsible from economic reasons) }\end{array}$ \\
\hline & $\begin{array}{l}\text { Technical effectiveness, } \\
\text { competition for access }\end{array}$ & $\begin{array}{l}\text { Energy and resources productivity, and exploitation in relations to pur- } \\
\text { chase price (goal: an increase to maximum physical possibilities) }\end{array}$ \\
\hline \multirow{5}{*}{ 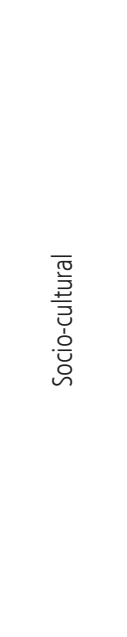 } & $\begin{array}{l}\text { Democracy, social ac- } \\
\text { ceptability }\end{array}$ & $\begin{array}{l}\text { Goals: delivering production and supply only to countries and enterpris- } \\
\text { es, where the rules of democracy and law principles are obeyed (mul- } \\
\text { tiparty system, free elections, human rights, freedom of creating trade } \\
\text { unions) }\end{array}$ \\
\hline & $\begin{array}{l}\text { Poverty liquidation, } \\
\text { durable confidence } \\
\text { of supply }\end{array}$ & $\begin{array}{l}\text { Contribution to reliable supply, easy usage and proper price (goals: } \\
\text { goods should not contain any natural resources, which cannot be used } \\
\text { in a sustainable way and they have to be as environmentally-friend- } \\
\text { ly as possible) }\end{array}$ \\
\hline & $\begin{array}{l}\text { Integration in existing } \\
\text { structures }\end{array}$ & $\begin{array}{l}\text { Goals: an increase of chances' equality, integration in existing structures, } \\
\text { low costs }\end{array}$ \\
\hline & Avoiding conflicts & $\begin{array}{l}\text { Goals: products and techniques should contribute to avoiding global } \\
\text { conflicts and shaping international justice, e.g. through limitation of def- } \\
\text { icit goods usage, the respect for competition principles }\end{array}$ \\
\hline & $\begin{array}{l}\text { Care of safety, quality } \\
\text { of life, health }\end{array}$ & $\begin{array}{l}\text { Threats, cost of the most dangerous accidents (goals: risk minimising, } \\
\text { discontinuation of goods production, which causes unacceptable risk } \\
\text { while using them or disposal of wastes) }\end{array}$ \\
\hline
\end{tabular}

Source: Own study on the basis of: H. Rogall, Ekonomia zrównoważonego rozwoju, ZYSK i S-KA, Poznań 2010, p. $315-316$.

The above presented assumptions of sustainable enterprise management, can rarely be implemented immediately. Most often these changes have evolutionary character, what by economics of sustainable development is considered to be a positive aspect, because it provides essential time for adjustment to new requirements ${ }^{14}$.

${ }^{14}$ Cf. H. Rogall, Ekonomia..., op. cit., p. 167. 


\section{SUSTAINABLE ENTERPRISE DEVELOPMENT VERSUS COMPETITIVE ADVANTAGE}

Modern enterprises act in a very turbulent surrounding, the ability of adjustment to dynamic changes is a key to survive and develop. That is why, enterprises pay huge attention to the analysis of long-term, socio-economic trends.

Undoubtedly, one of such trends, is adjustment of economy and society to requirements of sustainable development. Take for instance - Strategy Europe 2020 for one of key priorities it takes sustainable development, which assumes support of effective, environmentally-friendly and competitive economy ${ }^{15}$.

The second trend, which seems to be crucial from competitiveness view, is an increasing customer's influence, which will decide about long-term development programs of enterprises. In subject literature, there is a term: customer's economy, which means that, currently present consumers are better informed and more often want to adjust to proposed products, and conducted forms of activity of a certain enterprise - they expect that, an enterprise exists to solve their problems ${ }^{16}$. One of basic problems of modern society is degradation and environment pollution, and connected with it health and social threats. Rising social consumer's awareness, causes an increase in demand for sustainable products, but it has to be emphasized that, aware consumers not only rate a product, but also producer's activities ${ }^{17}$.

As a practice shows - providing consumers with products, which are in accordance with sustainable development assumptions, constitutes a chance to distinct offer and build a long-term competitive advantage ${ }^{18}$. However, it should be emphasized that, an enterprise's success, which acts in accordance with sustainable development assumptions, depends on many factors. The key ones include:

15 Cf. W. Janasz (ed.), Innowacje w zrównoważonym rozwoju organizacji, Difin, Warszawa 2011, p. 9.

${ }_{16}$ M. Hammer, Sztuka konkurowania w gospodarce XXI wieku. Plan dziatania, Helion, Gliwice 2006, p. 11-39.

${ }_{17}$ Cf. S. Zaremba-Warnke, Konsumeryzm a procesy integracji $i$ dezintegracji, „Ekonomia i Prawo", Vol. VIII, No. 1/2012, p. 74-81.

${ }^{18}$ Cf. e.g. K. Kearins, B. Klÿn, The Body Shop International, [in:] M. Charter, M.J. Polonsky (eds), Greener Marketing, Greenleaf Publishing, UK 1999, p. 285-299; R.J. Thomas, Prawdziwe historie nowych produktów, Prószyński i S-ka, Warszawa 2001, p. 96-105; G. Madhavan, B. Oakley, D. Green, D. Koon, P. Low (eds), Practicing Sustainability, Springer, New York 2012, p. 181-186; A. Baumast, J. Pape, Betriebliches Umweltmanagement. Nachbaltiges Wirtschaften in Unternehmen, Ulmer,Stuttgart 2008, p. 246-254, 259-263. 
- social engagement of owners and managers - a real belief that, economic, ecological and social goals can and should be treated equally important, and willingness to run business in a sustainable way;

- social engagement of other employees - awareness that, somebody's own work helps to solve social problems, rises employee's effectiveness and creativity, employees constitute one of the most important customer group of sustainable enterprise;

- full transparency and ethics of run business - enables reliable communication with customers about the values connected with sustainable development and protection of a very sensitive company's image, company which is socially responsible; sustainable enterprises are vulnerable to attacks concerning their honesty and social engagement;

- the subject of business, which is not contrary to sustainable development concept - e.g. enterprises from tobacco or chemical industry, can only try to recompense negative social results of their activities, but the profile of their activity excludes complete accomplishment of economics of sustainable development assumptions;

- knowledge and social responsibility level of stakeholders - allows for a long time to build and benefit from pioneer's position on the market, and also to build durable, good relations with key surrounding's groups, an enterprise can also actively - through proper communication - influence on stakeholders' attitude.

A spectacular example of an enterprise fulfilling the above mentioned conditions is Hipp GmbH \& Co. Vertrieb KG (Hipp), a leading manufacturer of ecological food market for children. Hipp bases its competitive advantage on the accomplishment of sustainable development principles. Hipp is a family enterprise, which has over 100 years tradition - it started its business activity as a small family business, and currently has its branches in several countries in Europe, and output markets in the whole world. A fact of functioning and stable development for such a long time proves durability of management. A crucial event in the development of this company was sustainable development principles admission as a basis of their activities, over 50 years ago. For all enterprise's activities, its owners from the very beginning vouch by their surname, which at the same time is a well-known brand in the whole world.

It is worth mentioning that, Hipp activity profile is predestined to the accomplishment of sustainable development principles. Hipp enterprise produces ecological food for infants and older children, what accomplishes sustainable development assumptions, such as providing durability growth of en- 
vironmental capital and responsibility for health and quality of life for future generations.

Ecological agriculture, which constitutes a basis for the production of all Hipp products contributes to natural landscape and biodiversity protection, improvements of quality and efficiency of soil, prevents from eco-systems pollution through artificial fertilizers, plant protection products and genetically modified organisms, allows to keep an appropriate level of ground water. Ecological agriculture has a positive influence on a long-term energetic balance - it generates energy surplus, while extensive agriculture uses more energy to produce agricultural products. Cultivating in accordance with nature, allows to solve financial problems of farmers, who are suppliers of Hipp enterprise ${ }^{19}$.

Hipp owners are inspired by principles and values, favourable for the accomplishment of sustainable development. In C. Hipp point of view, the aim of an enterprise's activities is not a short-term profit, but long-term sustainable development, which includes social company's responsibility. C. Hipp appreciates family life in multigenerational families, as an employer he takes care of his employees' development and enables them harmonious combination of their professional and personal life. Moreover, he emphasizes that, employees should have an opportunity of further education, in accordance with their changing interests. Employees in Hipp enterprise are also provided with very good social and health benefits ${ }^{20}$.

A basis of Hipp sustainable production are criteria, which significantly exceed guidelines of ecological agriculture in European Union. They concern, among others, such aspects like: using only ecological resources, a complete exclusion of genetically modified organisms, animal breeding in accordance with species requirements ${ }^{21}$. Logo placed on Hipp products fulfills all functions of an ecological label, enabling consumers to take a decision about a purchase.

Hipp bases its production mainly on regional resources. If it uses imported products, than it tries all the supplies to fulfil sustainable development and fair trade requirements, e.g. ecological bananas imported from Costa Rica are picked up on small farms, in wild forests, what prevents it from their cutting ${ }^{22}$.

${ }^{19}$ C. Hipp, Wolnosic, by czynić to inaczej. Moje życie. Moje wartości. Moje myślenie, Jedność, Kielce 2012, p. 230-245.

${ }^{20}$ Cf.: Ibidem, p. 11-21; Hipp GmbH \& Co. Vertrieb KG, Nachhaltigkeitsbericht 2012, http:// www.hipp.de/uploads/media/Nachhaltigkeitsbericht2012.pdf, p. 3-21, (23.09.2013).

21 Ibidem., p. 44.

${ }^{22}$ Ibidem, p. 52. 
Environmental management system Eco-Management and Audit Scheme (EMAS) and according to norm series ISO 14001, was implemented in Hipp. Confirmation of sustainable development of Hipp enterprise are also prizes awarded by independent bodies. For several years, Hipp company has been a laureate of prestigious prizes, e.g. ecological manger of the year, German sustainability prize, prizes for distinguishing environmental management. In 2011 and 2012 the company was taken by its consumers, to be the most sustainable enterprise in Germany ${ }^{23}$.

Hipp also runs a showcase ecological farm for their suppliers, to make them be able to satisfy rigorous requirements of ecological production. Also research projects are carried out in the farm, with the cooperation of universities, farmers associations and ecological processors Bioland, which allow to improve food processing, using ecological methods. Company's employees have a possibility of voluntary service for biodiversity protection. Hipp also enables students to visit a farm ${ }^{24}$.

Summing up, one can say that Hipp enterprise accomplishes all three strategic paths of the economics of sustainable development, and also fulfills most of criteria introduced in table $1^{25}$, and sustainability constitutes a basis of it competitive advantage. However, one should remember that, sustainable enterprise running is a dynamic process and means a necessity of continuous improvement and adjustment to higher requirements of socially aware stakeholders.

\section{CONCLUSIONS}

As research carried out in many enterprises show, it is possible to base a competitive advantage on the concept of sustainable development. Running enterprise in accordance with the assumptions of the economics of sustainable development provides adjustment to long-term, socio-economic trend, such as sustainable development and increasing customer's influence.

Taking into account the above mentioned tendencies, one can forecast that, enterprises will be under more pressure from the subjects of their surroundings, to make them act in a sustainable way. Those companies, which currently, voluntarily take into account sustainable development concept will be able to benefit from pioneer's position on the market, because adjusting to

\footnotetext{
23 Ibidem, p. 7-8.

24 Ibidem, p. 51.

25 Ibidem, p. 1-55.
} 
requirements of sustainable development is a process requiring time and often investment outlays.

\section{BIBLIOGRAPHY}

Baumast A., Pape J., Betriebliches Umweltmanagement. Nachbaltiges Wirtschaften in Unternehmen, Ulmer, Stuttgart 2008.

Gege M., Kosten senken durch Umweltmanagement, Verlag Vahlen, München 1997.

Hammer M., Sztuka konkurowania w gospodarce XXI wieku. Plan dziatania, Helion, Gliwice 2006.

Hipp C., Wolnośc, by czynić to inaczej. Moje życie. Moje wartości. Moje myślenie, Jedność, Kielce 2012.

Hipp GmbH \& Co. Vertrieb KG, Nachhaltigkeitsbericht 2012, http://www.hipp.de/ uploads/media/Nachhaltigkeitsbericht2012.pdf, (23.09.2013).

Instytut Ochrony Środowiska, Dokumenty końcowe Konferencji Narodów Zjednoczonych „Środowisko i Rozwój” w Rio de Janeiro w 1992 r., Warszawa1993.

Janasz W. (ed.), Innowacje w zrównoważonym rozwoju organizacji, Difin, Warszawa 2011.

Kearins K., Klÿn B., The Body Shop International, [in:] M. Charter, M.J. Polonsky (eds), Greener Marketing, Greenleaf Publishing, UK 1999.

Kiełczewski D. (ed.), Od koncepcji ekorozwoju do ekonomii zrównoważonego rozwoju, Wydawnictwo WSE w Białymstoku, Białystok 2009.

Kośmicki E., Nachbaltiger Konsum und das Welternährungsmodel, [in:] M. Wachowiak, D. Kiełczewski, H. Diefenbacher (eds.), Nachhaltiger Konsum? Die Entwicklung des Verbraucherverhaltens in Polen und Deutschland, FEST, Heidelberg 2011.

Madhavan G., Oakley B., Green D., Koon D., Low P. (eds), Practicing Sustainability, Springer, New York 2012.

Oberholz A., Umweltorientierte Unternehmensfübrung, Frankfurter Allgemeine Zeitung, Frenkfurt (Mein) 1990.

Poskrobko B. (ed.), Ekonomia zrównoważonego rozwoju w świetle kanonów nauki, Wydawnictwo WSE w Białymstoku, Białystok 2011.

Poskrobko B., (ed.), Teoretyczne aspekty ekonomii zrównoważonego rozwoju, Wydawnictwo WSE w Białymstoku, Białystok 2011.

Rogall H., Bausteine einer zukunftsfäbigen Umwelt und Wirtschaftspolitik, Duncker \& Humbolt, Berlin 2000.

Rogall H., Ekonomia zrównoważonego rozwoju, ZYSK i S-KA, Poznań 2010.

Rogall H., Nachbaltige Ökonomie, Metropolis, Marburg 2009.

Rogall H., Neue Umweltökonomie - Ökologische Ökonomie, Leske+Budrich, Opladen 2002.

Rogall H., Ökonomie der Nachbaltigkeit. Handlungsfelder für Politik und Wirtschaft, VS - Verlag, Wiesbaden 2004. 
Rogall H., Podstawowe zatożenia ekonomii zrównoważone, [in:] D. Kiełczewski (ed.), Od koncepcji ekorozwoju do ekonomii zrównoważonego rozwoju, Wyd. WSE w Bialymstoku, Białystok 2009.

Scheide W., Dold G., Enzler S., Efficient Eco-Management Using. ECO-Integral How to Save Costs and Natural Resources at the Same Time, [in:] M. Bennett, J. Jaap Bouma, T. Wolters (eds), Environmental Management Accounting: Informational and Institutional Developments, Kluwer Academic Publishers, Dordrecht 2002.

Söderbaum P., Understanding Sustainability Economics, Earthscan, London 2008.

Thomas R.J., Prawdziwe historie nowych produktów, Prószyński i S-ka, Warszawa 2001. Zaremba-Warnke S., Konsumeryzm a procesy integracji i dezintegracji, „Ekonomia i Prawo", Vol. VIII, No. 1/2012. 
